\title{
INFLUENCE OF POLISH ARMS, ARMOUR AND MILITARIA ON WESTERN EUROPE
}

BY

Z. S. LENKIEWICZ

UP to approximately the 15 th century the arms and the armament of a Polish knight were very similar in style to those used in the west: heavy armour, heavy sword, and heavy horse. However, in the face of the continuous attacks by Tartars, and later on Turks, on Polish territories, the enemy consisting of very light cavalry, on small but very quick and manageable horses, the heavy knights were of little use. Long before the 15 th century the armament and the tactics had to be slowly

FIG. 1
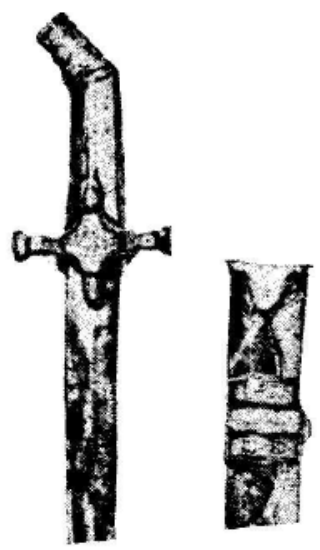

modified and adapted to the enemy's armament and strategems. The heavy straight sword was useless against fur hats and sheepskin covers of Tartars. The sabre as working in a more shearing way, had to be accepted. Poles now had to change over to much lighter and mobile troops. From Tartars was accepted the slighitly curved sabre with short quillons and open angle pommel (Fig. 1). Such sabres were produced mainly by Armenians, craftsmen living in Polish Lwow. The dominant type of sabre came to Poland with king Stefan Batory, formerly the duke 
of Transylvania: a slightly curved blade, straight cross-piece of long quillons and very long langlets sometimes nearly reaching the pommel (Fig. 2).

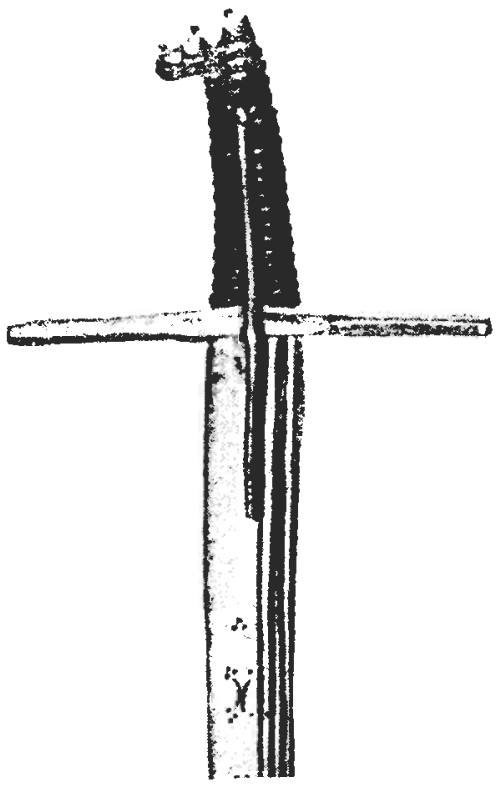

FIG. 2

The same type of sabre was used in Hungary. This was the period when the sabre started to influence Western Europe, this influence coming from Poland and Hungary. The types developing in parallel in Poland

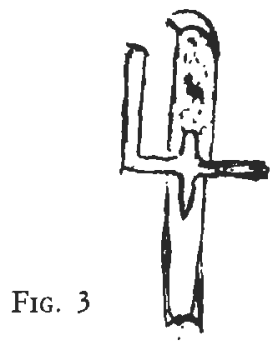

and Hungary, and influencing each other, were so similar that - unless they are marked by an inscription, a coat of arms, or a portrait of a king - it is nearly impossible to distinguish them and establish their 
origin. The Polish sabre was always slightly curved, double-edged near the tip and rather stiff, making it suitable for cutting and thrusting. Further development was a semi-closed hilt (Fig. 3) which Poles claim to be of Polish origin and Hungarians to be of Hungarian origin. One may accept, it was rather of Polish origin. Later the Hussar sabre was developed as a purely Polish type. This had a closed guard, but the most typical feature was an open-angle between the quillon and the knuckleguard (Fig. 4). Usually the knuckle-guard does not join the pommel. It springs when hit. This type is typically Polish. It did influence the

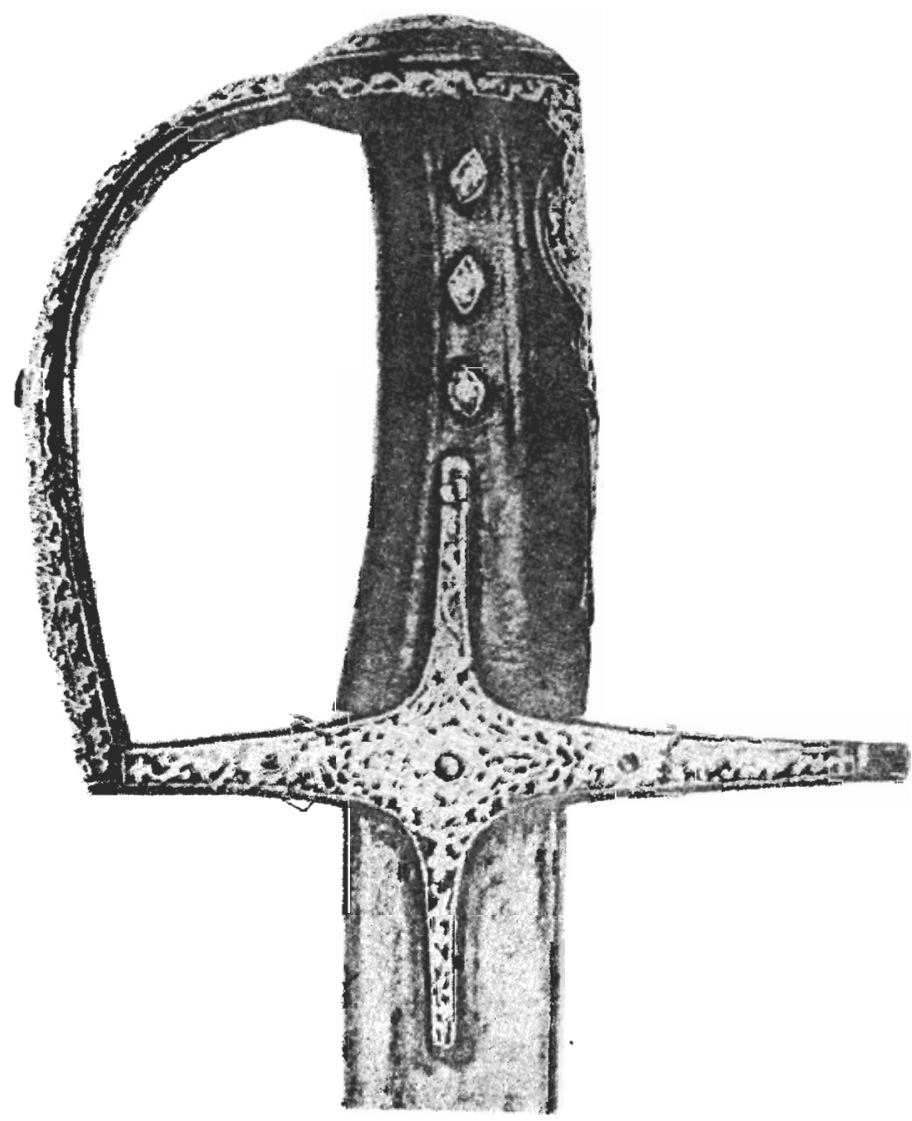

FIG. 4 
west, but the west accepted a more simple form, similar to Hungarian hussar hilt, with a straight angle between the quillon and the knuckleguard, which is joined to the pommel. Another detail of the Polish sabre is the thumb ring, rather of western palash origin, but very seldom used on the Hungarian sabre. This thumb ring was used on some western sabres. The Turkish origin, but accepted as Polish karabela-type hilt, with three buttons along the hilt, influenced to large extent the French hunting swords.

\section{The Lance}

The lance, practically out of use since the mediaeval jousts is of very different shape and use (Fig. 5). It was used in Poland and - after two years of requests to get it approved - in Polish Napoleonic cavalry, after Bonaparte had shown what could be done with it. It was introduced for the Polish lancer and cheveaux-légère regiments. The proper

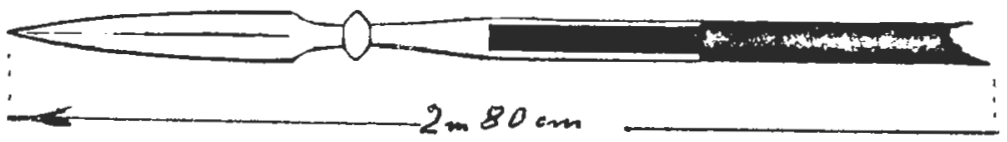

FIG. 5

use of the Polish lance is an art. One may fence with it, using it forwards, backwards and to the sides (it should not be confused with the Russian pike, which is useless for fencing). Following the Napoleonic period it was introduced in all lancer (uhlan) regiments throughout Europe, and it was used up to the first years of the twentieth century. The British lancer's lance is such a close reproduction of the Polish lance that even the Polish colours of red and white are used on the pendants. The Polish lance is comparatively short and light; its proportions were often spoilt in other countries by making it too long, too heavy and in general too clumsy to be used in its proper manner.

\section{The Helmet}

The Polish so-called hussarian shishague was developed in two ways. In the first place, it evolved from a Turkish helmet by the addition of a peak, ear covers, and initially a few small neck protecting laminations. The first such helmets were made in Germany on orders from Polish no- 
bility. The second route of development was from the so called «Kopalin», somewhat similar to the so-called war hat or a type of pikesman's helmet. This has added lobster-tail, laminations on the back for neck

FIG. 6

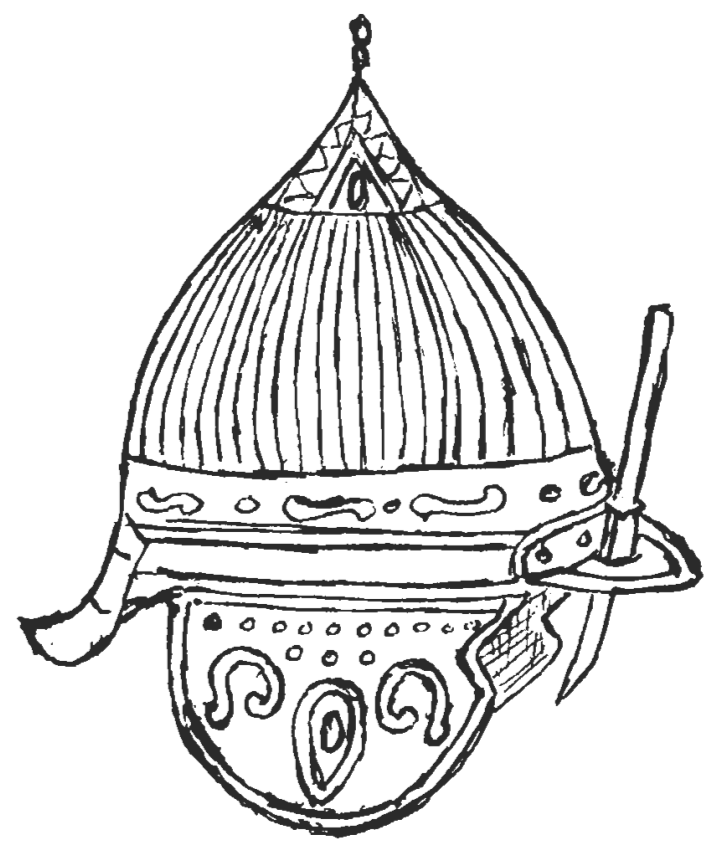

protection, possibly the first used in Europe, the brim narrowing to complete disappearance, adding instead ear covers and peak with a nasal bar (Figs. 6 and 7). From initially conical head on the Turkish type, it

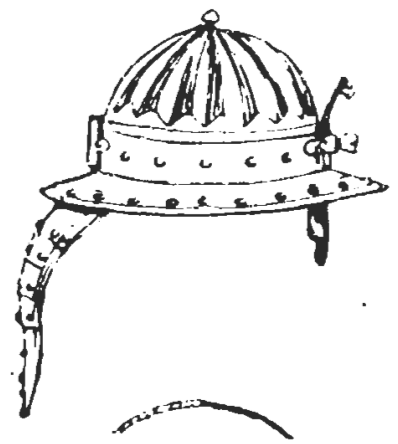

FIg. 7 
becomes a fully rounded head. From this typical Polish helmet was developed in the 17th century the more decorative so-called burgonet in western Europe. This is the nearest to the Polish helmet and may often be confused with it. The Pappenheimer helmet was merely a simplified form of the Polish helmet (Fig. 8). It has thinner metal, smaller earpieces, and simpler nasal bar; on top there is a knob with a hole to hang it from the saddle on long marches (Fig. 8). It was produced in quantities. As
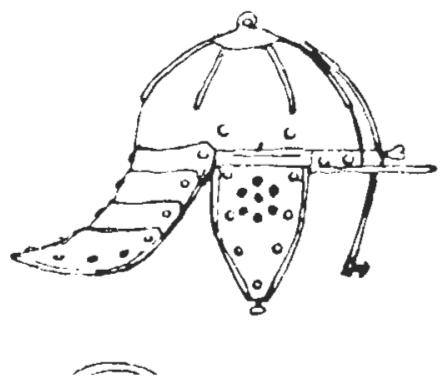

FIg. 8

many Poles had served with Pappenheimer, many of these helmets were later used in the Polish cavalry. The Cromwellian helmet is another derivative based on the Polish hussar helmet, having a hinged peak with an attached three-bar face cover.

\section{The Kaftan}

By the end of the 17th century the military coat became shorter, reaching to the knees, and was pleated at the hips; it was of oriental origin and came to western Europe via Poland with the Polish name of «kaftan». In France it was sometimes called «à la Polaque». In time the kaftan became shorter and came to be called «dolman». This was used particularly by the Hungarian hussars. In 1743 the so called Volontaires de Saxe were formed in France, whose uniforms were based on the Polish national dress. The hat was called «chapka», for some reason later twisted to «shapska». This was a fur-trimmed hat with square top, worn originally by peasants in the south-west of Poland. Later it was accepted by the nobility and it is most typically Polish. The «kaftan», later shortened, and now called dolman, was much used by different countries' light cavalry. After 1812 the French infantry changed their long dress to short jacket of distinctly Polish appearance. 


\section{ChevauX-LÉGÈre-Polonnais}

From 1797, when the Polish uhlan regiments were formed by General Dabrowski in Italy, and from 1807, when chevaux-légère were

FIG. 9

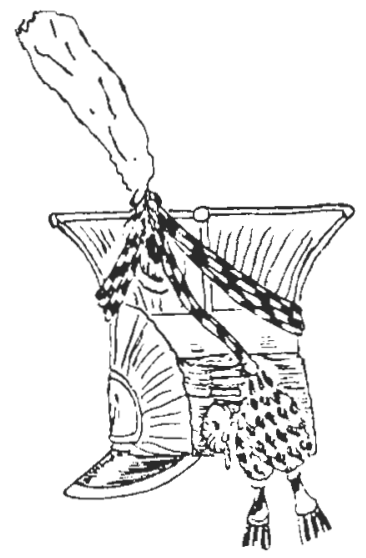

formed in the French army, the head-dress was entirely Polish, with the square top (Fig. 9). The so called «kurtka» was also of Polish origin, by name and shape (Fig. 10). This type of dress for light cavalry, generally later called lancers as in Britain or uhlans as in the other countries

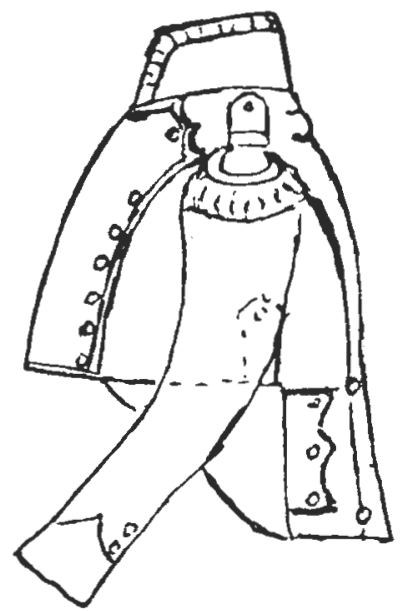

FIG. 10 
of western Europe, was used in all these countries with only minor changes. Later the «kurtka» was called in Germany «uhlanka». The British lancer's chapka is the nearest to the original Polish pattern. The other countries have modified the chapka to their own taste, sometimes into extravagant shapes, but always retaining the square top, the peak, and the cords reaching down to the shoulder. During the 18th century the Polish militaria were much in fashion in western Europe. So much that Austria used the name of «hajduk» for hussars cap. This name was of Turkish origin where it meant «marouder», but later in Poland meant servant-soldier. Europe accepted the name «palash» for their long known single edge rapiers. This name again, of eastern origin, came from Poland, used for the straight single edged sword. In 1770 Austrian newly created lancer formations retained the Polish names of «towarzysz» (tovarish) and «pocztowy» (postovi), on the regimental payrolls. In 1812 tsar Alexander created light cavalry regiments, Lithuanians, tartars and chevaux-légère. Both wore the Polish kurtka and chapka, and the nobles only, carrying lances, were called towarish.

\section{BIBLIOGRAPHY}

Bozheim, W.: Handbuch der Waffenkunde, Wien, 1890.

Botтet, Maurice: Monographie de l'Arme Blanche des Armées Françaises de Terre et de Mer, 1789-1870, Paris, 1959.

BRON Y BARWA: Warszawa, 1934-1939.

Crmarelli, Aldo: Arms and Armour, London, 1972.

Dziewanowski, W.: Zarys Dziejow Uzbrojenia w Polsce, Warszawa, 1935.

Gell, Jacopo: Guida del Raccoglitore e dell'Amatore di Armi Antiche, Milano, 1968.

HeAD, Michael G.: French Napoleonic Lancer Regiments, London, 1971.

JARNuSzkiewicz, C.: Szabla Wschodnia i jej typy narodowe, London, 1973.

Mollo, John: Military Fasbion, London, 1972.

SEITZ, Heribert: Blankwaffen I-II, Braunschweig, 1965-68.

Zygulski, Z.: Bron w Dawnej Polsce, Warszawa, 1975. 